\title{
ASSESSMENT OF STRESS LOAD AMONG POLISH AND ENGLISH DENTAL STUDENTS' DIVISIONS IN POLAND
}

\author{
Zofia Juszka ${ }^{1,2}$, Wojciech Marchewka ${ }^{3}$, Aleksandra Smolana ${ }^{4}$, Katarzyna Szczeklik5, Katarzyna Olszewska-Turek, \\ Bartłomiej W. Loster ${ }^{7}$, Jolanta E. Loster ${ }^{4}$ \\ 'Professor Loster's Orthodontic Clinic, Cracow, Poland \\ ${ }^{2}$ Students'Scientific Group of Integrated Dentistry, Department of Integrated Dentistry, Jagiellonian University Medical College, Cracow, Poland \\ ${ }^{3}$ Jagiellonian University Medical College, Cracow, Poland \\ ${ }^{4}$ Department of Dental Prosthodontics Dental Institute, Jagiellonian University Medical College, Cracow, Poland \\ ${ }^{5}$ Department of Integrated Dentistry, Jagiellonian University Medical College, Cracow, Poland \\ ${ }^{6}$ Chair of Psychiatry, Jagiellonian University Medical College, Cracow, Poland \\ ${ }^{7}$ Department of Orthodontics, Jagiellonian University Medical College, Cracow, Poland
}

\begin{abstract}
INTRODUCTION: Dental students are extremely stressed-out group of young people.

Овjectives: The aim of our study was to evaluate factors inducing most of the stress and identify students who are most susceptible to it.

MATERIAL AND METhods: A survey was carried out during a winter exam session of 2018 for both Polish (PL) and English (ENG)-speaking students at our University. Two questionnaires were used, including dental environmental stress (DES) questionnaire and perceived stress scale (PSS-10), through which, a correlation between students' questionnaires' responses from each year and their courses of study were analyzed.

RESULTS: 309 students from PL group demonstrated a response rate (rr) of 93\%, whereas in ENG group ( $n=61)$, rr was $70 \%$, with total rr of $89 \%$. Adjusting for year of study and age, ENG students had lower scores than PL students in both PSS-10 (by 2.341) and DES (by 0.286). In PL group, PSS-10 scores were highest in second-year students $(24.08 \pm 6.44)$, while DES scores peaked within third-year students $(1.91 \pm 0.46)$. In ENG group, there were no statistically significant differences in PSS-10 between years, and highest DES scores were noted in fifth-year students $(2.16 \pm 0.28)$. Most stressful factor at this University was study conditions, while a group that was most susceptible to stress turned out to be second-year, third-year PL students, and fifth-year ENG students.

Conclusions: The faculty should consider the results of the current study to improve the conditions for studying in order to reduce the already elevated level of stress of dental students.
\end{abstract}

KEY wORDS: psychological distress, DES, dental education, psychological tests, PSS10.

J Stoma 2021; 74, 3: 177-187

DOI: https://doi.org/10.5114/jos.2021.109185

\section{JOURNAL OF} STOMATOLOGY CZASOPISMO STOMATOLOGICZNE

ADDRESS FOR CORRESPONDENCE: Dr. Zofia Juszka, Professor Loster's Orthodontics, 4 Bartlomieja Nowodworskiego St., 30-433 Cracow, Poland, e-mail: zofia.loster@alumni.uj.edu.pl 


\section{INTRODUCTION}

Comparing to general population of other undergraduate courses, dental students are an exceptionally stressedout group of young people [1-3]. The pursuit of academic excellence and high demands of social inter-relationship, along with limited time available for relaxation, lead to work overload and burnout, with a negative impact on physical and psychological health, including mild somatic, depressive, and obsessive-compulsive symptomatology as well as anxiety and interpersonal sensitivity [1-4]. Because of a busy curriculum that occupies most of students' daytime hours, dental studies are a full-time job, and demands of dental schooling are frequently unlike anything that students have experienced in their previous education. Heavy emphasis on clinical science requires students to concentrate as much on manual skills as on more familiar academic skills [1-5]. Therefore, the consequences of persistent stress involve psycho-somatic and psychological distress, such as anxiety, depression, hostility, fear, and tension [4]. The most significant undesirable effect of stress, as far as dental education is concerned, is the impairment of effective intellectual function and detriment of learning [4, 6-8].

First study on stress load in dental students' environment was conducted in 1980 in the US by Garbee et al. [1] The authors created an original version of dental environmental stress (DES) questionnaire, which in following years was modified and used in many countries and institutions, including seventeen European universities [2, 3, 9-13], twelve in Asia [14-16, 16-25], eleven in North America [1, 5, 26-31], two in Africa [32, 33], and one in Australia [34]. DES originally contained 38 questions in five groups: study conditions, academic work and responsibilities, interaction with university administration, personal problems, and choice of professional career. Due to cultural differences, each study made minor DES adjustments. DES questionnaire has been demonstrated to cover important aspects of dental students' environment, but it did indicate ranges of normal, higher, or lower results. For this reason, many previous studies have combined DES questionnaire with other measures, including health behavior or general psychological well-being questionnaires [3, 26, 31, 35]. One of these questionnaires was perceived stress scale (PSS-10), which was introduced in 1983 by Cohen et al. and translated into many languages [36, 37]. The authors of this questionnaire designed it for people having at least junior high school education, and included simple, general, easy to understand, and relatively universal questions, despite specific differences between populations. Higher PSS-10 scores are associated with, for example, greater vulnerability to stressful life events, failure to quit smoking, depressive symptoms, and painful TMD (temporomandibular disorders) [36, 38, 39].

To our knowledge, there is no previous research in Poland on the above-mentioned subject. Although there has been similar studies conducted in other European countries, but in Poland, teaching is conducted in a traditional way, not using a problem-based method, which is popular in Western Europe. Moreover, there are cultural differences between Poland and other European countries, which additionally may influence the results. To date, there has been no similar research conducted in countries culturally related to Poland. Therefore, it seems necessary to evaluate stress load on dental students in Poland, which may lead to a recognition of stress-inducing factors specific for this population.

\section{OBJECTIVES}

The aim of our study was to answer following questions:

1. What are the factors that induce the most stress in dental students in our university?

2. Which students are the most susceptible to stress?

\section{MATERIAL AND METHODS}

\section{ETHICAL STATEMENT}

The research received an approval from a Jagiellonian University Bioethical Committee (No. 1072.6120. 230.2017).

\section{STUDY DESIGN: DESCRIPTIVE ANALYSIS}

The survey was performed within all dental students during the 2018 winter exam session, including students undertaking dental education in both Polish (PL) and English (ENG) languages at the University. Syllabuses for both the groups are identical, except the language of teaching. The survey was a paper-based questionnaire and was conducted just before an exam. Person administering the survey explained the aim of the study and indicated voluntary participation. All participants were requested to sign a consent form, with name and nationality provided. Consent forms were collected separately from the questionnaires, which were coded, allowing (whenever necessary) to identify students with PSS-10 scores above the norm in reference to psychologist. Only the main researchers (non-students) could decode the questionnaires. Inclusion criteria were correctly filled questionnaires and signed consent form.

Two questionnaires were used, including a version of dental environmental stress (DES) questionnaire modified by the authors to adjust to Polish medical universities, and perceived stress scale (PSS-10) questionnaire, which evaluated general mood and attitude to life. The modification was done based on a short questionnaire conducted in a group of 20 randomly selected students from different years of study. Students were 
TABLE 1. The DES questionnaire used in the study. English and Polish version. Questions were divided into the following categories: SC - study conditions, WR - academic work and responsibilities, IA - interaction with university administration, PP - personal problems, PC - choice of professional career

1. Over the last month, how often have you experienced stress due to your workload in university? Jak często w ciągu ostatniego miesiąca odczuwałeś/aś stres spowodowany liczbą zajęć na studiach?

2. Over the last month, how often have you experienced stress due to difficulties and demands of your studies? Jak często w ciągu ostatniego miesiąca odczuwałeś/aś stres spowodowany poziomem trudności zajęći i wymagań stawianych Ci na studiach?

3. Over the last month, how often have you experienced stress due to exams, tests, or grades? Jak często w ciągu ostatniego miesiąca odczuwałeś/ás stres spowodowany egzaminami, kolokwiami, zaliczeniami lub ocenami?

4. Over the last month, how often have you experienced stress due to competition with other students in your class? Jak często w ciągu ostatniego miesiąca odczuwałeś/aś stres spowodowany rywalizacją z innymi studentami z roku?

5. Over the last month, how often have you experienced stress due to responsibility of taking care of patients? Jak często w ciągu ostatniego miesiąca odczuwałeś/aś stres spowodowany odpowiedzialnością za opiekę nad pacjentami?

6. Over the last month, how often have you experienced stress due to fear of not being able to keep up with work (e.g., lack of time for studying for classes or tests)?

Jak często w ciągu ostatniego miesiąca odczuwałeś/aś stres spowodowany obawą przed niewypełnieniem swoich obowiązków na studiach (np. brak czasu na naukę na zajęcia, kolokwia)?

7. Over the last month, how often have you experienced stress due to difficulties learning clinical procedures? Jak często w ciągu ostatniego miesiąca odczuwałeś/aśs stres spowodowany trudnościami w nauce procedur klinicznych?

8. Over the last month, how often have you experienced stress due to patients and their attitude towards you and your work? Jak często w ciągu ostatniego miesiąca odczuwałeś/aś stres spowodowany podejściem i nastawieniem pacjentów do Ciebie i wykonywanej przez Ciebie pracy?

9. Over the last month, how often have you experienced stress due to working with patients of poor personal hygiene? Jak często w ciągu ostatniego miesiąca odczuwałeś/aś stres spowodowany pracą z pacjentami ze złą higieną osobistą?

10. Over the last month, how often have you experienced stress due to patients' attitude to dentistry? Jak często w ciągu ostatniego miesiąca odczuwałeś/aś stres spowodowany podejściem i nastawieniem pacjentów do stomatologii?

11. Over the last month, how often have you experienced stress due to atmosphere created by teaching staff during clinical activities? Jak często w ciągu ostatniego miesiąca odczuwałeś/aś stres spowodowany atmosferą stworzoną przez asystentów prowadzących zajęcia kliniczne?

12. Over the last month, how often have you experienced stress due to difficulties in learning precise manual skills, necessary for pre-clinical and laboratory work?

Jak często w ciągu ostatniego miesiąca odczuwałeś/aś stres spowodowany trudnościami w nauce precyzyjnych umiejętności manualnych niezbędnych na zajęciach przedklinicznych i laboratoryjnych?

13. Over the last month, how often have you experienced stress due to criticism of your work by teaching staff or patients? Jak często w ciągu ostatniego miesiąca odczuwałeś/aśs stres związany z krytyką Twojej pracy przez asystentów lub pacjentów?

14. Over the last month, how often have you experienced stress due to attitude of university administrative staff and its management toward students' needs?

Jak często w ciągu ostatniego miesiąca odczuwałeś/aśs stres spowodowany podejściem pracowników administracyjnych i władz uczelni do potrzeb studentów?

15. Over the last month, how often have you experienced stress due to rules that apply during clinics and classes? Jak często w ciągu ostatniego miesiąca odczuwałeś/aś stres związany z zasadami i regulaminem obowiązującym podczas zajęć?

16. Over the last month, how often have you experienced stress associated with your roommate? Jak często w ciągu ostatniego miesiąca odczuwałeś/aśs stres spowodowany relacją ze współlokatorem?

17. Over the last month, how often have you experienced stress related to romantic partner? Jak często w ciągu ostatniego miesiąca odczuwałeś/aśs stres spowodowany relacjami w związku z partnerem/partnerką?

18. Over the last month, how often have you experienced stress associated with other students in your group or class? Jak często w ciągu ostatniego miesiąca odczuwałeś/aś stres spowodowany relacją z innymi studentami z grupy lub roku?

19. Over the last month, how often have you experienced stress due to lack of time for rest and relaxation? Jak często w ciągu ostatniego miesiąca odczuwałeś/aś stres spowodowany brakiem czasu na odpoczynek?

20. Over the last month, how often have you experienced stress due to doubt whether dentistry is the right choice of career for you? Jak często w ciągu ostatniego miesiąca odczuwałeś/aś stres spowodowany niepewnością czy wybór zawodu lekarza dentysty to odpowiedni dla Ciebie wybór kariery? 
TABLE 1. Cont.

Item

21. Over the last month, how often have you experienced stress due to doubt whether you carry out you work professionally?

Jak często w ciągu ostatniego miesiąca odczuwałeś/aś stres spowodowany brakiem pewności, że profesjonalnie wykonujesz swoją pracę?

22. Over the last month, how often have you experienced stress due to marital problems?

Jak często w ciągu ostatniego miesiąca odczuwałeś/aś stres spowodowany problemami w związku małżeńskim?

23. Over the last month, how often have you experienced stress due to differences between your expectations of university and reality? Jak często w ciągu ostatniego miesiąca odczuwałeś/aś stres spowodowany różnicami pomiędzy Twoimi oczekiwaniami a tym, jak wyglądają zajęcia?

24. Over the last month, how often have you experienced stress due to concerns about starting a professional career as a dentist? Jak często w ciągu ostatniego miesiąca odczuwałeś/aś stres spowodowany z obawami przed rozpoczęciem samodzielnej pracy jako lekarz dentysta?

25. Over the last month, how often have you experienced stress associated with financial responsibilities? Jak często w ciągu ostatniego miesiąca odczuwałeś/aś stres spowodowany odpowiedzialnością finansową?

26. Over the last month, how often have you experienced stress due to concerns regarding own health? Jak często w ciągu ostatniego miesiąca odczuwałeś/aś stres spowodowany obawą o własny stan zdrowia?

27. Over the last month, how often have you experienced stress due to concerns about health of your family members? Jak często w ciągu ostatniego miesiąca odczuwałeś/aś stres spowodowany obawą o stan zdrowia członków rodziny?

28. Over the last month, how often did you experience stress related to your parents? Jak często w ciągu ostatniego miesiąca odczuwałeś/aś stres spowodowany relacjami z rodzicami?

29. Over the last month, how often have you experienced stress due to other personal issues? Jak często w ciągu ostatniego miesiąca odczuwałeś/aś stres spowodowany innymi problemami osobistymi?

TABLE 2. Sample description by year of study and gender

\begin{tabular}{|c|c|c|c|c|c|c|c|c|c|}
\hline & \multicolumn{6}{|c|}{ Gender } & \multirow{2}{*}{\multicolumn{2}{|c|}{ Response rate }} \\
\hline & & & \multicolumn{2}{|c|}{ Male } & \multicolumn{2}{|c|}{ Female } & & \\
\hline & & ENG & PL & \multicolumn{2}{|l|}{ ENG } & ENG & PL & ENG & PL \\
\hline \multicolumn{2}{|c|}{ Year 1} & 82 & 12 & 16 & 7 & 66 & 5 & $100.0 \%$ & $60.0 \%$ \\
\hline \multicolumn{2}{|c|}{ Year 2} & 52 & 14 & 15 & 6 & 37 & 8 & $87.0 \%$ & $74.0 \%$ \\
\hline \multicolumn{2}{|c|}{ Year 3} & 58 & 14 & 14 & 3 & 44 & 11 & $97.0 \%$ & $88.0 \%$ \\
\hline \multicolumn{2}{|c|}{ Year 4} & 50 & 11 & 13 & 3 & 37 & 8 & $91.0 \%$ & $85.0 \%$ \\
\hline \multicolumn{2}{|c|}{ Year 5} & 67 & 10 & 18 & 3 & 49 & 7 & $87.0 \%$ & $50.0 \%$ \\
\hline \multirow{2}{*}{\multicolumn{2}{|c|}{ Total }} & 309 & 61 & $76(24.5 \%)^{*}$ & $22(36.0 \%)^{*}$ & $233(75.2 \%)^{*}$ & $39(64.0 \%)^{*}$ & $93.0 \%$ & $70.0 \%$ \\
\hline & & 370 & & 98 & & 272 & & $89.0 \%$ & \\
\hline \multirow[t]{2}{*}{ Age } & $A v g \pm S D$ & $21.83 \pm 2.22^{* *}$ & $23.17 \pm 3.14^{* *}$ & & & & & & \\
\hline & Median & $22.0^{* * *}$ & $22 * * *$ & & & & & & \\
\hline
\end{tabular}

asked to answer 11 questions and respond to whether the problem presented in the question concerned them. After our modification, the questionnaire contained 29 items (from an original of 38) in the same structure as the original DES, i.e., five groups of item questions, including study conditions, academic work and responsibilities, interaction with university administration, personal problems and choice of professional career, with participants not being aware of this division [1]. The five groups of questions are presented in Table 1.

The original English version of DES was translated into Polish and then back to English. Then, Polish version was adjusted for compatibility with English one. The questionnaire asked the students how often in the last month they had felt or thought in various ways. There was a five-point answer scale, ranging from 0 as 'never' to 4 as 'very often'. Questions referring to roommates, romantic relationships, and marriage (No. 16, 17, and 22) had an additional option of 'not applicable'; if chosen, this item was not considered in a final score calculation. Final score was mean standard deviation of all applicable questions answered. Score for each group was calculated in the same way, i.e., mean standard deviation of all questions answered from each group. Since DES questionnaire does not have a set of norms indicating a result as 'normal stress level' or 'high stress level, we decided to use other questionnaire, which assesses general level of stress. The assessment of general stress level 
TABLE 3. Results without age and gender correction as mean score \pm standard deviation. Statistically significant results are bolded, $p<0.05 .{ }^{\dagger}$ normal distribution: Student's $t$-test. Other categories did not have normal distribution and the Mann-Whitney test was used

\begin{tabular}{|c|c|c|c|c|c|c|c|c|c|c|c|c|}
\hline \multirow{2}{*}{ Parameter } & \multicolumn{2}{|c|}{ All years } & \multicolumn{2}{|c|}{ Year 1} & \multicolumn{2}{|c|}{ Year 2} & \multicolumn{2}{|c|}{ Year 3} & \multicolumn{2}{|c|}{ Year 4} & \multicolumn{2}{|c|}{ Year 5} \\
\hline & PL & ENG & PL & ENG & PL & ENG & PL & ENG & PL & ENG & PL & ENG \\
\hline PSS-10 score & $\begin{array}{c}20.46 \\
\pm 6.55^{\dagger}\end{array}$ & $\begin{array}{c}17.23 \\
\pm 6.59^{\dagger}\end{array}$ & $\begin{array}{c}20.63 \\
\pm 6.87^{\dagger}\end{array}$ & $\begin{array}{c}13.90 \\
\pm 6.49^{\dagger}\end{array}$ & $\begin{array}{c}24.08 \\
\pm 6.44^{\dagger}\end{array}$ & $\begin{array}{r}19.36 \\
\pm 4.89^{\dagger}\end{array}$ & $\begin{array}{c}21.26 \\
\pm 5.01^{\dagger}\end{array}$ & $\begin{array}{r}17.00 \\
\pm 8.58^{\dagger}\end{array}$ & $\begin{array}{r}19.16 \\
\pm 6.44^{\dagger}\end{array}$ & $\begin{array}{r}16.55 \\
\pm 5.48^{\dagger}\end{array}$ & $\begin{array}{r}17.59 \\
\pm 6.07^{\dagger}\end{array}$ & $\begin{array}{c}19.30 \\
\pm 6.07^{\dagger}\end{array}$ \\
\hline Total DES & $\begin{array}{c}1.70 \\
\pm 0.57^{\dagger}\end{array}$ & $\begin{array}{c}1.48 \\
\pm 0.70^{\dagger}\end{array}$ & $\begin{array}{c}1.40 \\
\pm 0.54^{\dagger}\end{array}$ & $\begin{array}{l}0.67 \\
\pm 0.31^{\dagger}\end{array}$ & $\begin{array}{c}1.89 \\
\pm 0.70\end{array}$ & $\begin{array}{c}1.32 \\
\pm 0.49\end{array}$ & $\begin{array}{c}1.91 \\
\pm 0.46^{\dagger}\end{array}$ & $\begin{array}{l}1.69 \\
\pm 0.65^{\dagger}\end{array}$ & $\begin{array}{c}1.81 \\
\pm 0.47^{\dagger}\end{array}$ & $\begin{array}{c}1.69 \\
\pm 0.70^{\dagger}\end{array}$ & $\begin{array}{r}1.66 \\
\pm 0.50^{\dagger}\end{array}$ & $\begin{array}{c}2.16 \\
\pm 0.28^{\dagger}\end{array}$ \\
\hline Study conditions & $\begin{array}{c}2.72 \\
\pm 0.75\end{array}$ & $\begin{array}{c}2.56 \\
\pm 0.95\end{array}$ & $\begin{array}{c}2.52 \\
\pm 0.76\end{array}$ & $\begin{array}{c}1.50 \\
\pm 1.00\end{array}$ & $\begin{array}{c}3.11 \\
\pm 0.63\end{array}$ & $\begin{array}{c}2.62 \\
\pm 0.77\end{array}$ & $\begin{array}{c}3.07 \\
\pm 0.49^{\dagger}\end{array}$ & $\begin{array}{c}2.99 \\
\pm 0.84^{\dagger}\end{array}$ & $\begin{array}{c}2.66 \\
\pm 0.79\end{array}$ & $\begin{array}{c}2.65 \\
\pm 0.65\end{array}$ & $\begin{array}{c}2.39 \\
\pm 0.72^{\dagger}\end{array}$ & $\begin{array}{c}3.06 \\
\pm 0.60^{\dagger}\end{array}$ \\
\hline $\begin{array}{l}\text { Academic work } \\
\text { and responsibilities }\end{array}$ & $\begin{array}{c}1.11 \\
\pm 0.79\end{array}$ & $\begin{array}{c}1.02 \\
\pm 0.89\end{array}$ & $\begin{array}{c}0.44 \\
\pm 0.61\end{array}$ & $\begin{array}{c}0.19 \\
\pm 0.43\end{array}$ & $\begin{array}{c}0.93 \\
\pm 0.80\end{array}$ & $\begin{array}{c}0.6 \\
\pm 0.37\end{array}$ & $\begin{array}{c}1.58 \\
\pm 0.68\end{array}$ & $\begin{array}{c}1.46 \\
\pm 1.01\end{array}$ & $\begin{array}{c}1.51 \\
\pm 0.51\end{array}$ & $\begin{array}{c}1.18 \\
\pm 0.81\end{array}$ & $\begin{array}{l}1.37 \\
\pm 0.67^{\dagger}\end{array}$ & $\begin{array}{c}1.83 \\
\pm 0.65^{\dagger}\end{array}$ \\
\hline $\begin{array}{l}\text { Interaction with } \\
\text { administration }\end{array}$ & $\begin{array}{c}1.66 \\
\pm 0.95\end{array}$ & $\begin{array}{c}1.51 \\
\pm 1.01\end{array}$ & $\begin{array}{c}1.12 \\
\pm 0.92\end{array}$ & $\begin{array}{c}0.31 \\
\pm 0.36\end{array}$ & $\begin{array}{c}1.88 \\
\pm 1.04^{\dagger}\end{array}$ & $\begin{array}{c}1.43 \\
\pm 0.93^{\dagger}\end{array}$ & $\begin{array}{c}1.96 \\
\pm 0.85^{\dagger}\end{array}$ & $\begin{array}{c}1.62 \\
\pm 0.94^{\dagger}\end{array}$ & $\begin{array}{c}1.96 \\
\pm 0.96^{\dagger}\end{array}$ & $\begin{array}{c}2.11 \\
\pm 0.79^{\dagger}\end{array}$ & $\begin{array}{c}1.64 \\
\pm 0.69\end{array}$ & $\begin{array}{c}2.25 \\
\pm 0.59\end{array}$ \\
\hline Personal problems & $\begin{array}{c}1.52 \\
\pm 0.67\end{array}$ & $\begin{array}{c}1.33 \\
\pm 0.69\end{array}$ & $\begin{array}{c}1.50 \\
\pm 0.67^{\dagger}\end{array}$ & $\begin{array}{c}0.76 \\
\pm 0.45^{\dagger}\end{array}$ & $\begin{array}{c}1.86 \\
\pm 0.87\end{array}$ & $\begin{array}{c}1.21 \\
\pm 0.63\end{array}$ & $\begin{array}{c}1.40 \\
\pm 0.59^{\dagger}\end{array}$ & $\begin{array}{c}1.44 \\
\pm 0.59^{\dagger}\end{array}$ & $\begin{array}{c}1.47 \\
\pm 0.48^{\dagger}\end{array}$ & $\begin{array}{c}1.51 \\
\pm 0.89^{\dagger}\end{array}$ & $\begin{array}{c}1.41 \\
\pm 0.63^{\dagger}\end{array}$ & $\begin{array}{c}1.82 \\
\pm 0.45^{\dagger}\end{array}$ \\
\hline $\begin{array}{l}\text { Choice of professional } \\
\text { career }\end{array}$ & $\begin{array}{c}1.78 \\
\pm 0.89\end{array}$ & $\begin{array}{c}1.14 \\
\pm 0.84\end{array}$ & $\begin{array}{c}1.49 \\
\pm 0.92\end{array}$ & $\begin{array}{c}0.48 \\
\pm 0.49\end{array}$ & $\begin{array}{l}1.96 \\
\pm 1.09\end{array}$ & $\begin{array}{c}0.98 \\
\pm 0.65\end{array}$ & $\begin{array}{l}1.99 \\
\pm 0.72^{\dagger}\end{array}$ & $\begin{array}{l}1.07 \\
\pm 0.91^{\dagger}\end{array}$ & $\begin{array}{c}1.81 \\
\pm 0.83\end{array}$ & $\begin{array}{c}1.20 \\
\pm 0.77\end{array}$ & $\begin{aligned} & 1.78 \\
\pm & 0.76^{\dagger}\end{aligned}$ & $\begin{array}{l}2.17 \\
\pm 0.41^{\dagger}\end{array}$ \\
\hline
\end{tabular}

validated DES results and demonstrated whether high general stress level combined with high DES score.

PSS-10 questionnaire was applied to confirm DES scores, since PSS-10 is one of the most widely used psychological instruments for measuring perception of general stress, and is based on Lazarus's theory of stress appraisal $[7,36,40]$. It contains ten questions on feelings and thoughts experienced over the last month. In each question, the respondent is asked to state how often he or she felt a given way, using the same scale as DES. The score resulting from this questionnaire is calculated as a sum of all points, with a reverse response to four positively phrased items $[6,36]$. Maximum score indicated 40 points, with 20-40 showing high stress level, 14-19 medium stress lev$\mathrm{el}$, and 0-13 low stress level. Normal result was $14.2 \pm 6$ for people in the age range of our respondents (18 to 29 years) $[6,36]$. According to the website of Laboratory for the Study of Stress, Immunity, and Disease at the Department of Psychology, Carnegie Mellon University, Pittsburgh, USA, a permission is not needed to use PSS-10 for non-profit academic research, as is the case here. We used English version of PSS-10 for the ENG students and Polish version for the PL students [37].

\section{STATISTICAL ANALYSIS}

Correlations between students of each year, sex, age, and course of study were assessed as well as results of PSS10 , DES, and each group of questions in DES. Results were statistically analyzed using $\mathrm{R}$ software (version 3.5.1.) [41], with Student's $t$-test, Mann-Whitney test, Fisher's post-hoc LSD test (for normally distributed data), or Dunn's test (for non-normally distributed data). To deter- mine a correlation with age, PSS-10, and DES, Pearson's correlation coefficient (for normally distributed data) and Spearman's correlation coefficient (for non-normally distributed data) were applied. Correlation strength was interpreted as follows: $|\mathrm{r}| \geq 0.9$ as 'very strong correlation'; $0.7 \leq|\mathrm{r}|<0.9$ as 'strong correlation'; $0.5 \leq|\mathrm{r}|<0.7$ as' medium-strong correlation'; $0.3 \leq|\mathrm{r}|<0.5$ as 'weak correlation'; $|\mathrm{r}|<0.3$ as 'very weak correlation' (negligible) [42]. We checked for correlations between groups and corrected for age and sex, using linear regression model. Results were presented as a regression coefficient, with a $95 \%$ confidence interval. Normal distribution was verified using Shapiro-Wilk test, with a level of significance as 0.05 .

\section{RESULTS}

A total of 370 students were evaluated. Overall, the response rate was $89 \%$, with $93 \%$ for the PL students and $70 \%$ for the ENG group. The ENG students were significantly older than the PL students, but the median age was the same (22 years) for both the groups. Characteristics of the groups are shown in Table 2.

\section{COMPARISON OF PL AND ENG STUDENTS (EXCLUDING AGE AND GENDER ADJUSTMENTS)}

The PL group had significantly higher scores of both PSS-10 and DES than the ENG cohort. Also, the PL group had higher scores for DES questions on choice of professional career.

Greatest statistically significant differences were observed between fifth- and first-year students. The PL stu- 


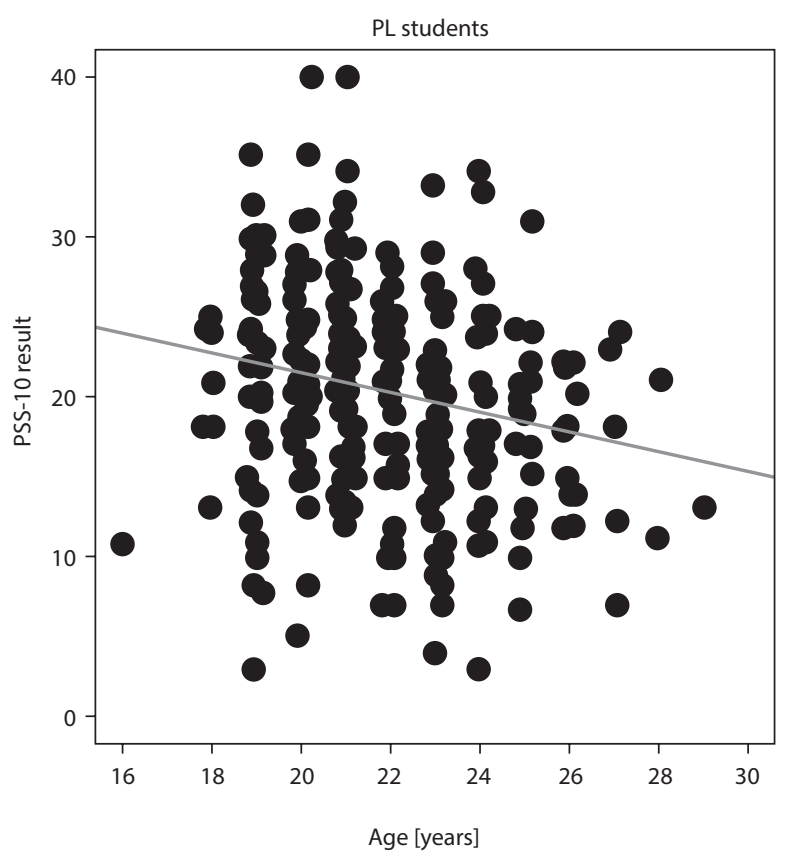

FIGURE 1. PSS-10 scores of PL students related to age $(p<0.05)$

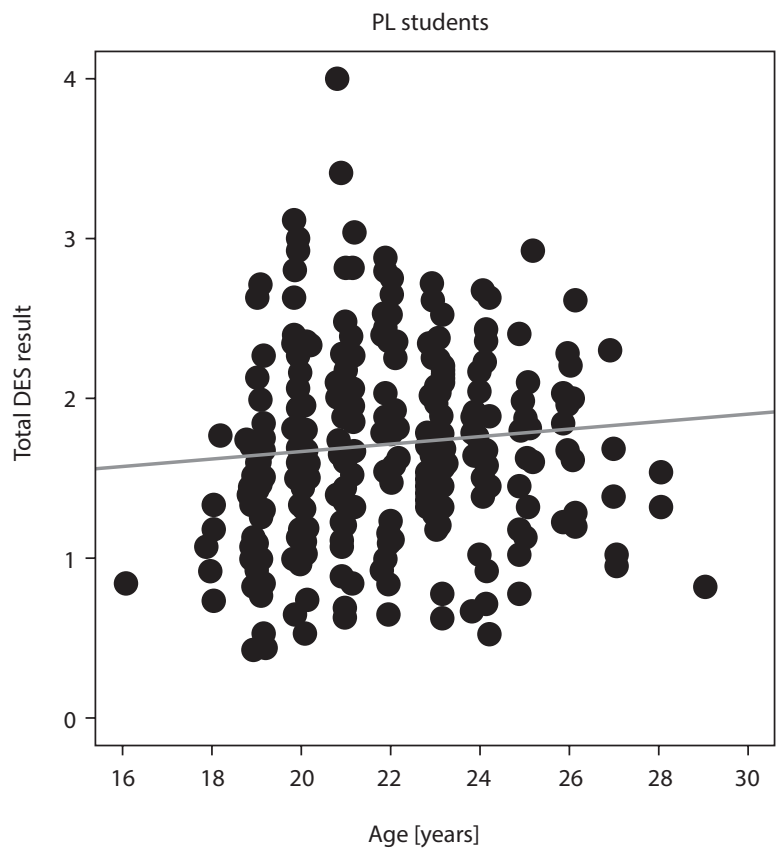

FIGURE 3. DES scores correlated to age in PL group $(p=0.71)$

dents had significantly lower scores in DES for study conditions, academic work, and responsibilities. Detailed results are presented in Table 3.

\section{COMPARISON OF PL AND ENG STUDENTS \\ (INCLUDING AGE AND GENDER ADJUSTMENT)}

Regression coefficient model showed that after the correction for age and gender, the differences in PSS-10

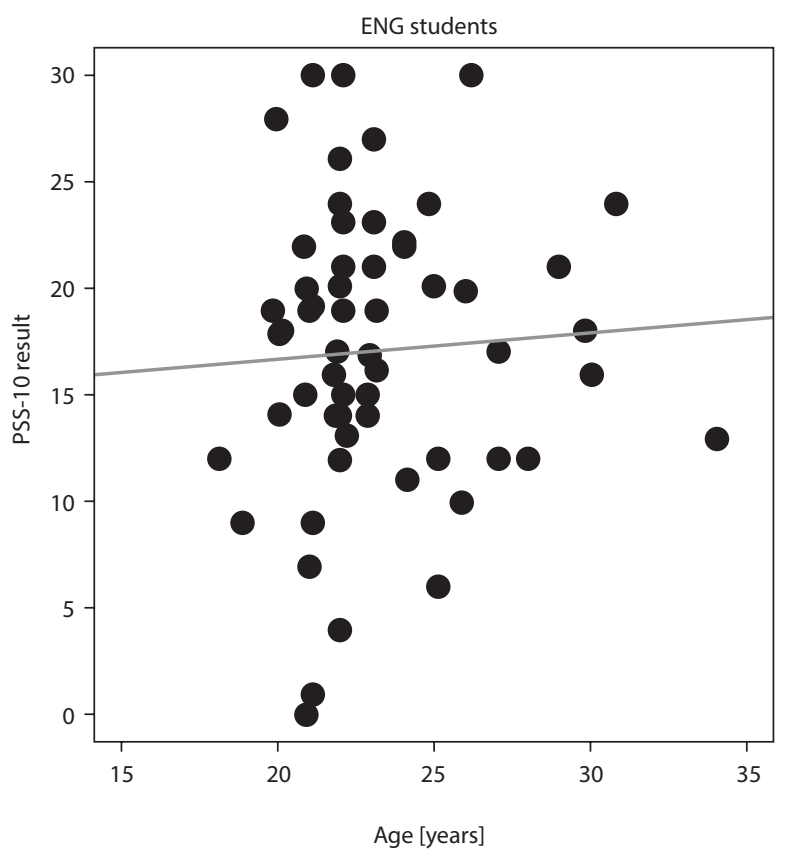

FIGURE 2. PSS-10 scores of ENG students related to age $(p=0.529)$

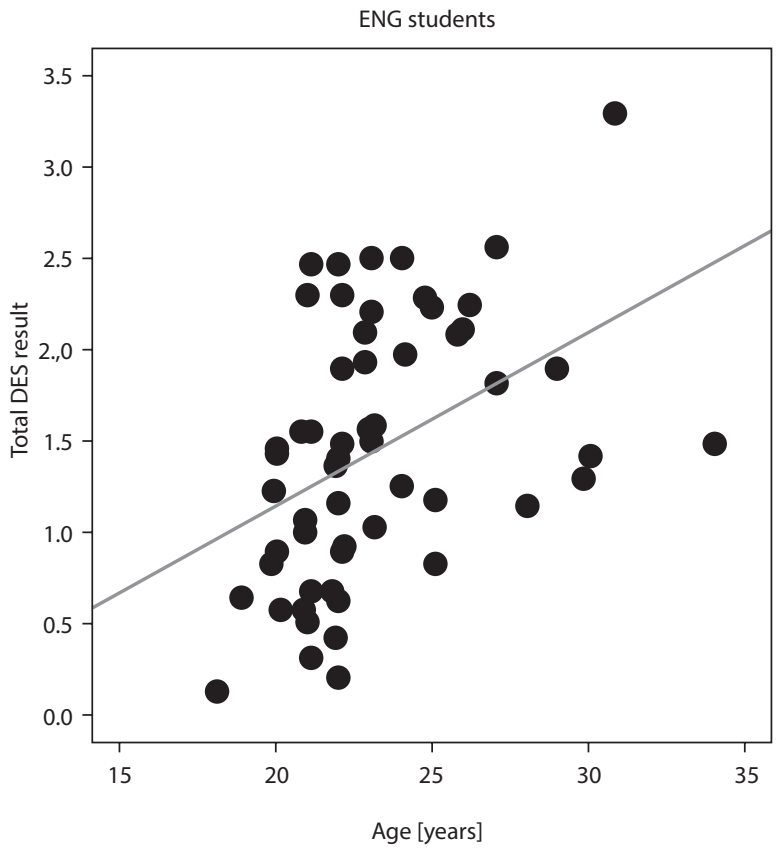

FIGURE 4. DES scores correlated to age in ENG group $(p<0.05)$

and DES scores between the PL and ENG groups were statistically significant. The ENG group presented lower PSS-10 score by 2.3 , and DES score was lower by 0.3 . For PSS-10, there were significant differences for first- and third-year students (ENG students had scores on average lower by 4.3 and 4.3 , respectively), and as for DES, there were significant differences for first-, second-, and fifth-year of study (ENG students had scores on average lower by $0.8,0.5$, and 0.5 , respectively). For the DES question group, significant differences were found for 
academic work and responsibilities (ENG students presented scores lower by 0.2 , on average), personal problems (ENG students had scores lower by 0.2 , on average), and choice of professional career (ENG students had scores lower by 0.7 , on average), with $p<0.05$. There were no significant differences between the whole investigated group in terms of study conditions or interaction with university administration. Significant differences for study conditions and personal problems were observed among first- and second-year students. There were significant differences for choice of professional career among first-, second-, and third-year students as well as for academic work and responsibilities among fourth- and fifth-year, and for interaction with university administration among first- and fifth-year students.

\section{GENDER DEPENDENCE}

Men and women differed significantly regarding total PSS-10 and DES scores, and in terms of study conditions, academic work, responsibilities, and choice of professional career. Moreover, the ENG students showed differences in personal problems. Women had significantly higher scores in PSS-10 when both groups considered, and when taking the PL and ENG groups separately. For DES, it was only in the ENG group that women had higher scores than men. The PL students did not show significant differences.

\section{AGE DEPENDENCE}

For both groups together and in the PL group only, age correlated negatively and significantly with total PSS-10 scores: the older the student, the lower the score. However, there was a positive and significant correlation with total DES score and academic work and responsibilities as well as interaction with university administration: the older the student, the higher the score. Figures 1-4 present these results.

\section{COMPARISON BETWEEN YEARS}

In order to determine the nature of this relationship, post-hoc analysis was performed in each case.

\section{PL AND ENG GROUPS TOGETHER}

The groups differed statistically significantly in six out of the seven compared parameters (DES total score, PSS-10 score, study conditions, academic work and responsibilities, interaction with university administration, and choice of professional career). There were no significant differences in personal problems scale. In case of PSS-10, students of years 1-3 had significantly higher scores than those of years 4-5, and second-year students had higher scores than those of first-year. For overall DES total score, first-year students had lower scores than those of later years. For study conditions, students of years 2 and 3 had higher scores than those of other years; for academic work and responsibilities, those of years 3-5 scored higher results than those of second-year, and those of year 2 scored higher than first-year students. For interaction with university administration and choice of professional career, first-year students presented lower scores than those of later years. The results are presented in Table 4 .

\section{PLSTUDENTS}

The groups differed statistically significantly in all parameters. For PSS-10, students of year 2 had higher scores than those of other years; those of year 1 and 3 scored higher than those of fifth-year. For DES, students of third-year presented higher scores than those of years 1 and 5, with those of years 2, 4, and 5 having higher scores than first-year students. In terms of academic work and responsibilities, the highest scores were obtained by students of years 3-5, followed by second-year students, with first-years scoring lowest. For study con-

TABLE 4. Comparison between years, PL and ENG groups together, as mean score \pm standard deviation. thormal distribution ANOVA plus post-hoc analysis result (LSD Fisher's t-test. Other categories did not have normal distribution and Kruskal-Wallis's test and post-hoc analysis result (Dunn's test) were used. Statistically significant results are bolded, $p<0.05$

\begin{tabular}{|l|c|c|c|c|c|c|}
\hline Parameter & Year 1 & Year 2 & Year 3 & Year 4 & Year 5 & Relationship between years \\
\hline PSS-10 score & $19.76 \pm 7.16$ & $23.09 \pm 6.41$ & $20.43 \pm 6.04$ & $18.68 \pm 6.32$ & $17.82 \pm 6.06$ & $\begin{array}{c}2>1,4,5 \\
3,1>5\end{array}$ \\
\hline Total DES score & $1.31 \pm 0.57$ & $1.78 \pm 0.70$ & $1.86 \pm 0.51$ & $1.79 \pm 0.52$ & $1.73 \pm 0.50$ & $3,4,2,5>1$ \\
\hline Study conditions† & $2.38 \pm 0.86$ & $3.01 \pm 0.68$ & $3.05 \pm 0.57$ & $2.66 \pm 0.76$ & $2.48 \pm 0.73$ & $3,2>4,5,1$ \\
\hline Academic work and responsibilities & $0.41 \pm 0.59$ & $0.86 \pm 0.74$ & $1.56 \pm 0.75$ & $1.45 \pm 0.58$ & $1.43 \pm 0.68$ & $3,4,5>2>1$ \\
\hline Interaction with administration & $1.02 \pm 0.91$ & $1.79 \pm 1.03$ & $1.9 \pm 0.87$ & $1.99 \pm 0.92$ & $1.72 \pm 0.70$ & $4,3,2,5>1$ \\
\hline Personal problems & $1.41 \pm 0.69$ & $1.73 \pm 0.86$ & $1.41 \pm 0.58$ & $1.48 \pm 0.57$ & $1.46 \pm 0.62$ & \\
\hline Choice of professional career & $1.36 \pm 0.94$ & $1.76 \pm 1.09$ & $1.81 \pm 0.84$ & $1.7 \pm 0.85$ & $1.83 \pm 0.74$ & $5,3,2,4>1$ \\
\hline
\end{tabular}


ditions, second-year and third-year students presented higher scores than those of other years, while students of fourth-year scored higher than those of fifth-year. In terms of interaction with university administration, first-years had the highest scores; for personal problems, second-years scored the highest. For choice of professional career, second-year and third-year students demonstrated higher scores than first-years. The results are shown in Table 5.

\section{COMPARISON OF DES SUB-SCALES}

For both language groups and for all years, the most stressful factor was study conditions. Among all PL students, the second most stressful factor was choice of professional career, along with personal problems for first-year and second-year PL students. Interaction with university administration and academic work and responsibilities were the least stressful factors for all years' students. Personal problems were the least stressful in students of 3-, 4-, and 5-year. Among the ENG students, the changes were more differential. The data is presented in Table 6 .

\section{DISCUSSION}

The aim of the study was to evaluate stress level and factors inducing stress, and to identify a group of students that is most susceptible to stress among dental students in the University. The study was the first of its kind to be conducted at a Polish university. The response rate was $89 \%$, which was considered high compared to other studies on this topic. Research investigating stress level are important for not only future dentists, but also for university departments or faculties, which can provide improvement of study conditions. Those have been demonstrated to be stressful for students of every year of their university education. Long-term stress is undesirable and may cause severe health problems [43]. Previous research have shown that stress is a factor that can induce various disorders, including cardiovascular disease, diabetes, and depression [43-45].
According to L. Harris Poll 46, the mean PSS-10 score for people aged 18-29 was $14.2 \pm 6$. In the current study, the mean PSS-10 score was $20.5 \pm 6.6$ for the PL students, and 17.2 \pm 6.5 for the ENG group $(p<0.001)$. This shows that dental students are significantly more stressed-out than people of the same age in general population [36, 47]. Our study demonstrated that both the groups experienced high level of stress. The PL group was more stressed-out, and the difference was statistically significant. In addition, other author's research revealed dental students as more stressed-out than persons in general population $[3,9,10]$. In a study, Pau's reported ENG group having similar mean PSS-10 score of students, in which PSS-10 score was found to increase with age. In the ENG students of our study, there was no significant difference in age, and in the PL students, there was a decrease observed [12].

The correlation between age and DES was significant in the ENG group for every aspect of DES, and it was always positive (Figure 4). In the PL group, DES scores were stable, with no significant differences. In the beginning of their education, the first-year ENG students' DES scores were much below that of PL students, but by the end of a degree, the scores increased to become much greater than that of the PL group. Comparing years, the PL group had the highest DES scores within thirdyears, while in the ENG group, it was for those of fifthyear. In our University curriculum, clinical classes begin in year 3, the year with the highest DES scores. A similar occurrence has been observed in studies in Canada and in the US $[26,30]$. In our research, females in the PL and ENG groups had higher stress levels than males in PSS-10 and three out of five DES categories. These results are in line with studies conducted at foreign universities, with females showing higher stress levels [2, 5, 11, 19, 29]. However, in a study by Muirhead et al., there were no such differences [26]. Wilson et al. made an interesting distinction between recently graduated dentists and those who had begun their professional career earlier, and found gender differences in stress level only to be significant in the second group [48].

TABLE 5. Comparison between years in PL students as mean score \pm standard deviation. †normal distribution ANOVA plus post-hoc analysis result (Fisher's LSD t-test). Other categories did not have normal distribution and the KruskalWallis test plus post-hoc analysis result (Dunn's test) were used. Statistically significant results are bolded, $p<0.05$

\begin{tabular}{|c|c|c|c|c|c|c|}
\hline Parameter & Year 1 & Year 2 & Year 3 & Year 4 & Year 5 & Relationship between years \\
\hline PSS-10 score† & $20.63 \pm 6.87$ & $24.08 \pm 6.44$ & $21.26 \pm 5.01$ & $19.16 \pm 6.44$ & $17.59 \pm 6.07$ & $2>3,1,4,53,1>5$ \\
\hline Total DES score & $1.40 \pm 0.54$ & $1.89 \pm 0.70$ & $1.91 \pm 0.46$ & $1.81 \pm 0.47$ & $1.66 \pm 0.50$ & $3>5,12,4,5>1$ \\
\hline Study conditions & $2.52 \pm 0.76$ & $3.11 \pm 0.63$ & $3.07 \pm 0.49$ & $2.66 \pm 0.79$ & $2.39 \pm 0.72$ & $2,3>4,1,5,4>5$ \\
\hline Academic work and responsibilities & $0.44 \pm 0.61$ & $0.93 \pm 0.80$ & $1.58 \pm 0.68$ & $1.51 \pm 0.51$ & $1.37 \pm 0.67$ & $3,4,5>2>1$ \\
\hline Interaction with administration & $1.12 \pm 0.92$ & $1.88 \pm 1.04$ & $1.96 \pm 0.85$ & $1.96 \pm 0.96$ & $1.64 \pm 0.69$ & $3,4,2,5>1$ \\
\hline Personal problems & $1.5 \pm 0.67$ & $1.86 \pm 0.87$ & $1.4 \pm 0.59$ & $1.47 \pm 0.48$ & $1.41 \pm 0.63$ & $2>1,4,5,3$ \\
\hline Choice of professional career & $1.49 \pm 0.92$ & $1.96 \pm 1.09$ & $1.99 \pm 0.72$ & $1.81 \pm 0.83$ & $1.78 \pm 0.76$ & $3,2>1$ \\
\hline
\end{tabular}


TABLE 6. Comparison of DES subscales among PL and ENG students as mean score \pm standard deviation. There are significant differences among each year. No normal distribution in groups, Friedman test plus post hoc analysis (paired Wilcoxon test with Bonferroni correction)

\begin{tabular}{|c|c|c|c|c|c|c|}
\hline Year & $\begin{array}{l}\text { Study } \\
\text { conditions } \\
\text { (A) }\end{array}$ & $\begin{array}{l}\text { Academic } \\
\text { work and } \\
\text { responsibilities } \\
\text { (B) }\end{array}$ & $\begin{array}{l}\text { Interaction with } \\
\text { administration } \\
\text { (C) }\end{array}$ & $\begin{array}{c}\text { Personal } \\
\text { problems } \\
\text { (D) }\end{array}$ & $\begin{array}{l}\text { Choice } \\
\text { of professional } \\
\text { career } \\
\text { (E) }\end{array}$ & $\begin{array}{l}\text { Relationship between } \\
\text { categories }\end{array}$ \\
\hline
\end{tabular}

\begin{tabular}{|c|c|c|c|c|c|c|}
\hline \multicolumn{7}{|l|}{ PL students } \\
\hline Year 1 & $2.52 \pm 0.76$ & $0.44 \pm 0.61$ & $1.12 \pm 0.92$ & $1.50 \pm 0.67$ & $1.49 \pm 0.92$ & $A>D, E>C>B$ \\
\hline Year 2 & $3.11 \pm 0.63$ & $0.93 \pm 0.80$ & $1.88 \pm 1.04$ & $1.86 \pm 0.87$ & $1.96 \pm 1.09$ & $A>E, C, D>B$ \\
\hline Year 3 & $3.07 \pm 0.49$ & $1.58 \pm 0.68$ & $1.96 \pm 0.85$ & $1.40 \pm 0.59$ & $1.99 \pm 0.72$ & $A>E, C>B, D$ \\
\hline Year 4 & $2.66 \pm 0.79$ & $1.51 \pm 0.51$ & $1.96 \pm 0.96$ & $1.47 \pm 0.48$ & $1.81 \pm 0.83$ & $A>C, E, B, D, C>B, D$ \\
\hline Year 5 & $2.39 \pm 0.72$ & $1.37 \pm 0.67$ & $1.64 \pm 0.69$ & $1.41 \pm 0.63$ & $1.78 \pm 0.76$ & $A>E, C, D, B, E>D, B, C>B$ \\
\hline
\end{tabular}

\begin{tabular}{|c|c|c|c|c|c|c|}
\hline \multicolumn{7}{|l|}{ ENG students } \\
\hline Year 1 & $1.5 \pm 1.00$ & $0.19 \pm 0.43$ & $0.31 \pm 0.36$ & $0.76 \pm 0.45$ & $0.48 \pm 0.49$ & $A>B$ \\
\hline Year 2 & $2.62 \pm 0.77$ & $0.60 \pm 0.37$ & $1.43 \pm 0.93$ & $1.21 \pm 0.63$ & $0.98 \pm 0.65$ & $A>C, D, E, B, C>B$ \\
\hline Year 3 & $2.99 \pm 0.84$ & $1.46 \pm 1.01$ & $1.62 \pm 0.94$ & $1.44 \pm 0.59$ & $1.07 \pm 0.91$ & $A>C, B, D, E$ \\
\hline Year 4 & $2.65 \pm 0.65$ & $1.18 \pm 0.81$ & $2.11 \pm 0.79$ & $1.51 \pm 0.89$ & $1.20 \pm 0.77$ & $A>D, E, B, C>E, B$ \\
\hline Year 5 & $3.06 \pm 0.60$ & $1.83 \pm 0.65$ & $2.25 \pm 0.59$ & $1.82 \pm 0.45$ & $2.17 \pm 0.41$ & $A>B, D$ \\
\hline
\end{tabular}

As with studies, the factor inducing the most stress in students in our research was study conditions, regardless of the year and language applied [1-3, 5, 19, 30, 35]. This aspect seems to be quite universal and in need of improvement. The second most important factor among the PL students was choice of professional career. Among the ENG group and in studies from other universities, choice of professional career was associated with patient's treatment $[3,19,26,30,35]$. Only a study of Westerman et al. observed that the most stressful factor among students at the end of their course was stress associated with graduation and the choice of professional career [5].

Among the PL students, there were no significant differences in DES, but the ENG students started their studies with much lower DES scores than that of the PL students. However, the level of this factor increased, to become much higher than that in the PL group at the end of their studies. These results may be interpreted as indicating that the ENG students did not perceive high stress level at the beginning of their education (according to PSS-10, medium stress level), but that professional responsibility (DES) increased over time, evoking stress (Figures 2 and 4). However, among the PL students, general stress level decreased with age (though remained high), while stress associated with professional responsibility remained at the same level (Figures 1 and 3). Although this observation agree with a Cohen's research, where PSS-10 score was observed to decrease with age, difference in age and stress relationship between students werefoundinone-norm section only(18-29yearsold) [36]. Thus, a more probable explanation could be cultural differences between groups.
This study has shown that ENG and PL students are susceptible to different stress factors and perceive dental studies differently. The PL students seemed to be more stressed in generally (as shown by their higher PSS-10 scores), but the ENG students appeared more worried about their professional career (as shown by an increase in DES scores with age and year). This may be caused by a great national differentiation in the ENG group as well as different paths of PL and ENG students after graduation. After university graduation, PL students who wish to become fully-qualified to practice dentistry in Poland must pass a national exam and undergo a year of vocational training, during which, they have no full clinical responsibility. On the other hand, ENG students may, for example, return to their motherland, where they are recognized as fully-qualified to practice, with full professional responsibility. Thus, PL students may feel that they still have time to study and develop after their graduation, and therefore do not feel as much of responsibility during teaching, as their English-speaking counterparts. Some ENG students may stay in Poland and undertake the same vocational training as PL students, and afterwards work in Poland or other European country.

It is important to note that this study was done in 2018, and it would be valuable to re-conduct it in the near future in order to compare stress level in students before and after lockdown associated with COVID-19 pandemic, which without a doubt, is a great stress factor itself $[49,50]$.

\section{LIMITATIONS}

The results of the present study must be generalized with care when used in different populations. It is import- 
ant to note, that our survey was conducted just before exams, during the most stressful time in an academic year. However, questions in the survey were concerning feelings of a previous month, not the day of exam. The other concern may be the small number of ENG participants. Even though the response rate was high (70\%), it resulted from the fact that there were 20 students per year only in the English division, with other study group of the same number of participants.

\section{CONCLUSIONS}

The current study confirmed our hypothesis that dental students are significantly more stressed-out than their counterparts in the general population. The most stressful factors in this group included study conditions and choice of professional career as well as females being more susceptible to stress than males. These findings should be taken into consideration by the faculty, which should provide less stressful study conditions for the students, as it may otherwise lead to general health problems. This research should be re-conducted to investigate reasons for females being more stressed then males.

\section{ACKNOWLEDGEMENT}

Authors would like to thank Joanna Wiewióra, DDS, Natalia Banduła-Biela, DDS and Valeriia Ishchenko, DDS for their invaluable assistance in conducting this survey and collecting questionnaires. The study was finances by financial resources from Students' Scientific Society, Jagiellonian University Medical College, Students' Grant Contest 2017.

\section{CONFLICT OF INTEREST}

The authors declare no potential conflicts of interest with respect to the research, authorship, and/or publication of this article.

\section{References}

1. Garbee WH, Zucker SB, Selby GR. Perceived sources of stress among dental students. J Am Dent Assoc 1939 1980; 100: 853-857.

2. Polychronopoulou A, Divaris K. Perceived sources of stress among Greek dental students. J Dent Educ 2005; 69: 687-692.

3. Gorter R, Freeman R, Hammen S, Murtomaa H, Blinkhorn A, Humphris G. Psychological stress and health in undergraduate dental students: fifth year outcomes compared with first year baseline results from five European dental schools. Eur J Dent Educ 2008; $12: 61-68$.

4. Lloyd C, Musser LA. Psychiatric symptoms in dental students. J Nerv Ment Dis 1989; 177: 61-69.

5. Westerman GH, Grandy TG, Ocanto RA, Erskine CG. Perceived sources of stress in the dental school environment. J Dent Educ 1993; 57: 225-231.

6. Roberti JW, Harrington LN, Storch EA. Further psychometric support for the 10-Item version of the Perceived Stress Scale. J Coll Couns 2006; 9: 135-147.
7. Lazarus RS. Psychological Stress and the Coping Process. New York: McGraw-Hill; 1966.

8. Orsini C, Tricio J, Tapia D, Segura C. How dental students' course experiences and satisfaction of their basic psychological needs influence passion for studying in Chile. J Educ Eval Health Prof [Internet] 2019 [cited 2020 Sep 9];16. Available from: http://www. jeehp.org/DOIx.php?number=344

9. Humphris G, Blinkhorn A, Freeman R, et al. Psychological stress in undergraduate dental students: baseline results from seven European dental schools. Eur J Dent Educ 2002; 6: 22-29.

10. Polychronopoulou A, Divaris K. Dental students' perceived sources of stress: a multi-country study. J Dent Educ 2009; 73: 631-639.

11. Schéle IA, Hedman LR, Hammarström A. A model of psychosocial work environment, stress, and satisfaction among dental students in Sweden. J Dent Educ 2012; 76: 1206-1217.

12. Pau AKH, Croucher R. Emotional intelligence and perceived stress in dental undergraduates. J Dent Educ 2003; 67: 1023-1028.

13. Heath JR, Macfarlane TV, Umar MS. Perceived sources of stress in dental students. Dent Update 1999; 26: 94-98, 100.

14. Ng V, Koh D, Mok B, Lim LP, Yang Y, Chia SE. Stressful life events of dental students and salivary immunoglobulin A. Int J Immunopathol Pharmacol 2004; 17 (2 Suppl): 49-56.

15. Rajab LD. Perceived sources of stress among dental students at the University of Jordan. J Dent Educ 2001; 65: 232-241.

16. Sugiura G, Shinada K, Kawaguchi Y. Psychological well-being and perceptions of stress amongst Japanese dental students. Eur J Dent Educ 2005; 9: 17-25.

17. Acharya S. Factors affecting stress among Indian dental students. J Dent Educ 2003; 67: 1140-1148.

18. Al-Omari WM. Perceived sources of stress within a dental educational environment. J Contemp Dent Pract 2005; 6: 64-74.

19. Al-Sowygh ZH. Academic distress, perceived stress and coping strategies among dental students in Saudi Arabia. Saudi Dent J2013; 25: 97-105.

20. Kumar S, Dagli RJ, Mathur A, Jain M, Prabu D, Kulkarni S. Perceived sources of stress amongst Indian dental students. Eur J Dent Educ 2009; 13: 39-45.

21. Morse Z, Dravo U. Stress levels of dental students at the Fiji School of Medicine. Eur J Dent Educ 2007; 11: 99-103.

22. Naidu RS, Adams JS, Simeon D, Persad S. Sources of stress and psychological disturbance among dental students in the West Indies. J Dent Educ 2002; 66: 1021-1030.

23. Peker I, Alkurt MT, Usta MG, Turkbay T. The evaluation of perceived sources of stress and stress levels among Turkish dental students. Int Dent J 2009; 59: 103-111.

24. Rosli TI, Abdul Rahman R, Abdul Rahman SR, Ramli R. A survey of perceived stress among undergraduate dental students in Universiti Kebangsaan Malaysia. Singapore Dent J 2005; 27: 17-22.

25. Yap AU, Bhole S, Teo CS. A cross-cultural comparison of perceived sources of stress in the dental school environment. J Dent Educ 1996; 60: 459-464.

26. Muirhead V, Locker D. Canadian dental students' perceptions of stress and social support. Eur J Dent Educ 2008; 12: 144-148.

27. Burk DT, Bender DJ. Use and perceived effectiveness of student support services in a first-year dental student population. J Dent Educ 2005; 69: 1148-1160.

28. Grandy TG, Westerman GH, Mitchell RE, Lupo JV. Stress among first-year dental students. J Dent Educ 1984; 48: 560-562.

29. Goldstein MB. Sources of stress and interpersonal support among first-year dental students. J Dent Educ 1979; 43: 625-629.

30. Murphy RJ, Gray SA, Sterling G, Reeves K, DuCette J. A comparative study of professional student stress. J Dent Educ 2009; 73: 328-337.

31. Silverstein ST, Kritz-Silverstein D. A longitudinal study of stress in first-year dental students. J Dent Educ 2010; 74: 836-848.

32. Hendricks SJ, Joshi A, Crombie K, Moola MH. Perceived sources of stress among black dental students in South Africa. J Dent Educ 1994; 58: 406-410.

33. Sofola OO, Jeboda SO. Perceived sources of stress in Nigerian dental students. Eur J Dent Educ 2006; 10: 20-23. 
34. Sanders AE, Lushington K. Effect of perceived stress on student performance in dental school. J Dent Educ 2002; 66: 75-81.

35. Elani HW, Allison PJ, Kumar RA, Mancini L, Lambrou A, Bedos C. A systematic review of stress in dental students. J Dent Educ 2014; 78: 226-242.

36. Cohen S, Kamarck T, Mermelstein R. A global measure of perceived stress. J Health Soc Behav 1983; 24: 385-396.

37. Juczyński Z, Ogińska-Bulik N. NPSR: Narzędzia Pomiaru Stresu i Radzenia Sobie ze Stresem. Warsaw: Pracownia Testów Psychologicznych; 2009 [In Polish].

38. Maślak-Bereś M, Loster JE, Wieczorek A, Loster BW. Evaluation of the psychoemotional status of young adults with symptoms of temporomandibular disorders. Brain Behav 2019; e01443.

39. Osiewicz M, Lobbezoo F, Loster B, Wilkosz M, Naeije M, Ohrbach R. Research Diagnostic Criteria for Temporomandibular Disorders (RDC/TMD) - the Polish version of a dual-axis system for the diagnosis of TMD. RDC/TMD Form. Open J Stomato 2013; 66: 576-649.

40. Lazarus RS, Folkman S. Stress, Appraisal, and Coping. Springer; 1984.

41. R Core Team. R: A language and environment for statistical computing. R Foundation for Statistical Computing [Internet]. Vienna, Austria: 2017. Available from: https://www.R-project.org/.

42. Hinkle DE, Wiersma W, Jurs SG. Applied Statistics for the Behavioral Sciences. $5^{\text {th }}$ ed. Boston: Houghton Mifflin; 2003.

43. Mayer SE, Lopez-Duran NL, Sen S, Abelson JL. Chronic stress, hair cortisol and depression: a prospective and longitudinal study of medical internship. Psychoneuroendocrinology 2018; 92: 57-65.

44. Miller GE, Blackwell E. Turning up the heat: inflammation as a mechanism linking chronic stress, depression, and heart disease. Curr Dir Psychol Sci 2006; 15: 269-272.

45. Surwit RS, Schneider MS, Feinglos MN. Stress and diabetes mellitus. Diabetes Care 1992; 15: 1413-1422.

46. Cohen S, Williamson GM. Perceived stress in a probability sample of the United States. In: The social psychology of health. Thousand Oaks, CA, US: Sage Publications, Inc; 1988. p. 31-67.

47. Cohen S. Perceived Stress Scale [Internet]. 1994. Available from http://www.mindgarden.com/documents/PerceivedStressScale. pdf (Accessed: 2.12.2019).

48. Wilson RF, Coward PY, Capewell J, Laidler TL, Rigby AC, Shaw TJ. Perceived sources of occupational stress in general dental practitioners. Br Dent J 1998; 184: 499-502.

49. Feinstein RE, Kotara S, Jones B, Shanor D, Nemeroff CB. A health care workers mental health crisis line in the age of COVID-19. Depress Anxiety 2020; 37: 822-826.

50. Mosheva M, Hertz-Palmor N, Ilan SD, et al. Anxiety, pandemicrelated stress and resilience among physicians during the COVID-19 pandemic. Depress Anxiety 2020; 37: 965-971. 